\title{
Ornithine decarboxylase inhibition and the uterotrophic response to oestrogen in rats
}

\author{
Kay Marshall and Judith Senior \\ School of Studies in Pharmacology, University of Bradford, Bradford BD7 1DP, U.K.
}

\begin{abstract}
Summary. Pretreatment of mature ovariectomized rats with DL-5a-difluoromethylornithine (DFMO) inhibits the 6-h uterine blood flow response to oestradiol and also depresses the stimulatory effect of oestradiol on wet and dry uterine weight. Results from this study indicate that polyamine synthesis is implicated in the uterine response to oestrogen.
\end{abstract}

\section{Introduction}

Ornithine decarboxylase (EC 4.1.1.17) catalyses the first, and possibly rate-limiting, reaction in the biosynthesis of putrescine and the polyamines spermidine and spermine. Interest in the polyamines has grown because of increasing recognition of their essential roles in cellular growth, multiplication and differentiation (Tabor \& Tabor, 1976; Fozard et al., 1980a). Direct proof of the functional role of ornithine decarboxylase has been difficult to obtain, mainly because of the lack of tools with which to manipulate selectively the polyamine biosynthetic pathway. However, a potent and selective inhibitor of ornithine decarboxylase that acts through the mechanism of substrate-induced irreversible inhibition has been developed. This compound DL- $\alpha$-difluoromethylornithine (DFMO) has been shown to be an effective and selective inhibitor of ornithine decarboxylase in vivo (Prakash, Schecter, Grove \& Koch-Weser, 1978; Danzin, Jung, Grove \& Bey, 1979; Manni \& Wright, 1983).

As oestrogen selectively stimulates new RNA synthesis and thereafter increases protein synthesis, a useful system for studying polyamine synthesis and accumulation is the oestrogenstimulated uterus of the ovariectomized rat (Russell \& Taylor, 1971).

In the present study DFMO was used to inhibit ornithine decarboxylase and so investigate the possible role of the polyamines in the uterotrophic response to oestrogen.

\section{Materials and Methods}

Mature virgin female rats of a CD-derived Sprague-Dawley random-bred strain from the Animal House, University of Bradford, were used throughout and were housed in light (07:00-19:00 h) and temperature $\left(18^{\circ} \mathrm{C}\right)$ controlled rooms. Food and water were available ad libitum. All the animals used in this study were bilaterally ovariectomized at least 14 days before further experimentation and were randomly assigned to groups.

Measurement of blood flow. The microsphere technique (previously described by Phaily \& Senior, 1978) was used to determine blood flow in the rat anaesthetized with sodium pentobarbitone $\left(60 \mathrm{mg} \mathrm{kg}^{-1}\right)$. The microspheres used were $15 \mu \mathrm{m}$ in diameter (NEN-Trac, New England Nuclear, Boston, MA, U.S.A.) uniformly labelled with ${ }^{46} \mathrm{Sc}$ and suspended in $10 \%(\mathrm{w} / \mathrm{v})$ dextran containing $0.01 \%(\mathrm{w} / \mathrm{v})$ Tween 80 . Uterine blood flows were calculated using wet weights of tissues. When dry weights are quoted the tissues were dried until their weights remained constant. 
Drug administration. Oestradiol (oestra-1,3,5(10)-triene-3,17ß-diol) (BDH, Poole, U.K.) was dissolved in a $10 \%(\mathrm{v} / \mathrm{v})$ solution of propylene glycol and was administered intravenously (i.v.) at a dose level of $0.5 \mu \mathrm{g} \mathrm{kg}^{-1}$ into the tail vein of the conscious rat. DFMO was dissolved in $0.9 \%(\mathrm{w} / \mathrm{v})$ sodium chloride solution and given by the intraperitoneal (i.p.) route, at a dose level of $200 \mathrm{mg} \mathrm{kg}^{-1}$. The solvents used did not have any effect on uterine blood flow or weight and these results have been grouped as control values.

Statistical analysis. The results (expressed as mean \pm s.e.m.) were compared using Student's $t$ test (two tailed) Snedecor \& Cochran, 1979).

\section{Results}

From the results of preliminary studies, involving doses of DFMO ranging from 25 to $400 \mathrm{mg} \mathrm{kg}^{-1}$, it was decided to use a dose of $200 \mathrm{mg} \mathrm{kg}^{-1}$ for further work. Fozard, Prakash \& Grove $(1980 \mathrm{~b})$ have shown that this dosage is sufficient to suppress ornithine decarboxylase activity. None of the doses of DFMO used had any effect on organ blood flow or the appearance of the animals in general.

\section{Effect of oestradiol and DFMO on uterine blood flow}

Uterine blood flow increased rapidly after the injection of oestradiol. The marked elevation seen $3 \mathrm{~h}$ after oestradiol treatment was beginning to decline by $6 \mathrm{~h}$ after oestradiol injection (Table 1).

Table 1. The effect of $0.5 \mu \mathrm{g}$ oestradiol $\mathrm{kg}^{-1}$ and $200 \mathrm{mg}^{\mathrm{DFMO} \mathrm{kg}}{ }^{-1}$ used separately and together on uterine blood flow and weight in rats

\begin{tabular}{|c|c|c|c|c|c|c|c|c|c|}
\hline \multirow[b]{2}{*}{ Treatment } & \multirow{2}{*}{$\begin{array}{c}\text { No. } \\
\text { of } \\
\text { rats }\end{array}$} & \multirow{2}{*}{$\begin{array}{l}\text { Body } \\
\text { wt } \\
(\mathrm{g})\end{array}$} & \multirow{2}{*}{$\begin{array}{c}\text { Cardiac } \\
\text { output } \\
\left(\mathrm{ml} \mathrm{min}^{-1}\right)\end{array}$} & \multicolumn{2}{|c|}{ Uterine blood flow } & \multirow{2}{*}{$\begin{array}{c}\% \text { Cardiac } \\
\text { output to } \\
\text { uterus }\end{array}$} & \multicolumn{2}{|c|}{$\begin{array}{l}\text { Uterine weight } \\
(\mathrm{mg})\end{array}$} & \multirow{2}{*}{$\begin{array}{c}\text { Water } \\
\text { content } \\
\text { of uteru } \\
(\mathrm{mg})\end{array}$} \\
\hline & & & & $\mathrm{ml} \mathrm{min}-1$ & $\underset{100 \mathrm{~g}^{-1}}{\mathrm{ml} \mathrm{min}}$ & & Wet & Dry & \\
\hline (a) None & 9 & 304 & 93 & 0.065 & 66 & 0.067 & $\begin{array}{r}107 \\
+8\end{array}$ & 23 & 85 \\
\hline DFMO & 6 & $\frac{ \pm 1}{323}$ & $\begin{array}{l} \pm 0 \\
118\end{array}$ & $\begin{array}{l} \pm 0.01 \\
0.089\end{array}$ & $\begin{array}{c} \pm 12 \\
78\end{array}$ & 0.076 & 123 & $\frac{1}{25}$ & 99 \\
\hline Oestradiol & 8 & $\begin{array}{l} \pm 6 \\
321 \\
+7\end{array}$ & $\begin{array}{l} \pm 10 \\
104 \\
+11\end{array}$ & $\begin{array}{l} \pm 0.01 \\
0.94 \\
+0.10^{* *}\end{array}$ & $\begin{array}{l} \pm 14 \\
735 \\
\pm 66^{* *}\end{array}$ & 0.96 & $\begin{array}{l} \pm 15 \\
128 \\
+7\end{array}$ & $\begin{array}{l} \pm 3 \\
35 \\
+2^{*}\end{array}$ & 93 \\
\hline $\begin{array}{l}\text { DFMO + } \\
\text { oestradiol }\end{array}$ & 7 & $\begin{array}{l}311 \\
\pm 9\end{array}$ & $\begin{array}{l}108 \\
\pm 3\end{array}$ & $\begin{array}{c}0.96 \\
\pm 0 \cdot 11^{* * \ddagger}\end{array}$ & $\begin{array}{r}910 \\
+103^{* *+}+\end{array}$ & 0.89 & $\begin{array}{l}107 \\
\pm 55 \dagger\end{array}$ & $\begin{array}{l}23 \\
\pm 1 \ddagger\end{array}$ & 84 \\
\hline $\begin{array}{l}\text { (b) None } \\
\text { (control) }\end{array}$ & 9 & $\begin{array}{r}304 \\
+7\end{array}$ & $\begin{array}{r}93 \\
\pm 6\end{array}$ & $\begin{array}{l}0.065 \\
\pm 0.01\end{array}$ & $\begin{array}{r}66 \\
\pm 12\end{array}$ & 0.067 & $\begin{array}{r}107 \\
\pm 8\end{array}$ & $\begin{array}{l}23 \\
\pm 3\end{array}$ & 85 \\
\hline DFMO & 6 & $\begin{array}{l}315 \\
+4\end{array}$ & $\begin{array}{r}104 \\
+4\end{array}$ & $\begin{array}{l}0.080 \\
+0.03\end{array}$ & $\begin{array}{r}87 \\
+28\end{array}$ & 0.080 & $\begin{array}{r}97 \\
+7\end{array}$ & $\begin{array}{l}20 \\
+2\end{array}$ & 76 \\
\hline Oestradiol & 8 & $\begin{array}{l}306 \\
\pm 5\end{array}$ & $\begin{array}{r}90 \\
+5\end{array}$ & $\begin{array}{c}0.56 \\
+0.07^{* *}\end{array}$ & $\begin{array}{c}394 \\
\pm 46^{* *}\end{array}$ & 0.63 & $\begin{array}{l}144 \\
\pm 8^{*}\end{array}$ & $\begin{array}{l}27 \\
\pm 1\end{array}$ & 117 \\
\hline $\begin{array}{l}\text { DFMO + } \\
\text { oestradiol }\end{array}$ & 6 & $\begin{array}{l}328 \\
\pm 8\end{array}$ & $\begin{array}{l}115 \\
\pm 15\end{array}$ & $\begin{array}{l}0.25 \\
\pm 0.04 * \pi\end{array}$ & $\begin{array}{l}233 \\
\pm 40+^{*}\end{array}$ & $0 \cdot 24$ & $\begin{array}{l}114 \\
\pm 9+\end{array}$ & $\begin{array}{c}20 \\
\pm 29\end{array}$ & 94 \\
\hline
\end{tabular}

* Values are mean \pm s.e.m.

$\dagger$ DFMO was given $1 \mathrm{~h}$ before a single injection of oestradiol. Measurements were made (a) $3 \mathrm{~h}$ and (b) $6 \mathrm{~h}$ after oestradiol injection.

$\$$ Values are significantly different from those of control group: ${ }^{*} P<0.05 ;{ }^{* *} P<0.001$.

T Values are significantly different from those of oestradiol alone group: $\dagger P<0.05 ; \ddagger P<0.001 ; \uparrow P<0.005$. 
DFMO alone had no significant effect on blood flow, but when given in conjunction with oestradiol a reduction in uterine blood flow was seen $6 \mathrm{~h}$ after oestradiol administration (Table 1). None of the treatments had a significant effect on the blood flow through the other organs investigated (kidney, stomach, duodenum, adrenal and spleen) and cardiac output was also unaffected by the treatements. In the non-oestrogen-stimulated uterus the number of microspheres in the organ was inadequate for accurate blood flow determination but in these animals there was a balance between right and left kidney flow and also right and left adrenal flow, indicating that the distribution of microspheres is uniform. If the number of microspheres injected is significantly higher than 100000 haemodynamic effects may occur in the rat (Tsuchiya, Walsh \& Frohlich, 1977).

\section{Effect of oestradiol and DFMO on uterine weight and water content}

When given alone, DFMO had no effect on uterine weights. After oestradiol injection uterine wet weight was increased, and this increase was significant $6 \mathrm{~h}$ after injection. The increase in uterine water content was reflected in the wet weight values. The initial increase in uterine dry weight had declined $6 \mathrm{~h}$ after oestradiol injection.

DFMO pretreatment suppressed the increase in wet and dry weight in response to oestradiol both at 3 and $6 \mathrm{~h}$ after the oestrogen treatment. Uterine water content was correspondingly decreased.

\section{Discussion}

The early stimulation of uterine blood flow by oestradiol was unaffected by pretreatment with DFMO, but blood flow values $6 \mathrm{~h}$ after oestradiol administration were below the control value. Oestradiol is known to cause a sustained elevation of uterine blood flow (up to $72 \mathrm{~h}$ after a single i.v. injection $0.5 \mu \mathrm{g} \mathrm{kg}^{-1}: \mathrm{K}$. Marshall \& J. Senior, unpublished observation) and the suppression of this increase in blood flow by DFMO pretreatment, with the subsequent inhibition of polyamine synthesis, may indicate that this response to oestradiol is partly dependent on protein synthesis. The protein synthesis inhibitor, cycloheximide (used at a dose which should not affect prostaglandin synthesis; Castracane \& Jordan, 1976), has also been shown to inhibit the early hyperaemic response to oestradiol (Majid, 1981).

It is possible that oestradiol exerts its action on ornithine decarboxylase via the products of the cyclo-oxygenase and/or lipoxygenase pathways. Wing \& Rillema (1983) suggest that prostaglandins may modulate the action of prolactin on ornithine decarboxylase activity via a cAMP-dependent mechanism. Nakadate, Yamamoto, Ishii \& Kato (1982) have published data which suggest that lipoxygenase products are also involved in induction of ornithine decarboxylase. Inhibition of prostaglandin synthesis also reduces the hyperaemic response to oestradiol by up to $50 \%$ (Phaily \& Senior, 1978).

The DFMO suppression of true uterine growth, indicated by dry weight in this study, is more marked $3 \mathrm{~h}$ after oestradiol administration. At this time, ornithine decarboxylase activity is increasing steeply and reaches a peak about $4 \mathrm{~h}$ after injection (Bulger \& Kupfer, 1976; Levy, Mester \& Baulieu, 1981; Lavia, Stohs \& Lemon, 1983; Webster, Zaloudek \& Inman, 1984). In fact, the increase in dry weight usually seen $3 \mathrm{~h}$ after oestradiol administration has been abolished (dry weight remaining at control levels). However, $6 \mathrm{~h}$ after oestrogen injection, dry weight remains depressed. These results appear to be in contradiction to those obtained by Rorke \& Katzenellenbogen (1984) who found that although DFMO did inhibit ornithine decarboxylase activity and the subsequent increase in spermidine concentration, uterine weight was unaffected by DFMO pretreatment, but these authors did not measure uterine dry weight and the rats used were sexually immature. Levels of ornithine decarboxylase do differ; there is evidence that activity of the enzyme declines with age (Das \& Kanungo, 1982), activity being greatest during periods of rapid growth or regeneration. 
Moreover, the results presented here refer to an acute oestradiol effect. Alternatively, these differences could indicate that enzyme inhibition may have switched the emphasis from the pathway of polyamine biosynthesis catalysed by ornithine decarboxylase to an alternate route of polyamine regulation. Slotkin et al. (1982) also found differences between the responses of mature and immature animals to DFMO and have postulated that pathway divergences may occur in different tissues at different developmental stages. These authors also found that the concentration of spermine, unlike putresine and spermidine, was refractive to acute change.

Pretreatment of rats with DFMO also decreased uterine water content in response to oestradiol, thus indicating that the decrease in wet weight could be attributed to a reduced water intake. This may be suggestive of a connection between protein synthesis and uterine wet weight. If such a link does exist, then uterine oedema may also be mediated by the receptor-genome interaction. Indeed, the induction of ornithine decarboxylase by oestradiol can be blocked by protein synthesis inhibitors, such as actinomycin D (Russell \& Taylor, 1971), which have been shown to suppress selectively the genomic response to oestrogen (Tchernitchin \& Galand, 1982). There are also results which suggest that ornithine decarboxylase activity reflects changes in nuclear oestrogen receptor levels. With respect to water imbibition, Chen, Kyriakidis \& Canellakis (1982) found that low concentrations of colchicine (which disrupts the microtubule-microfilament cytoskeleton of the cell) inhibits enhancement of ornithine decarboxylase. Colchicine can, therefore, block eosinophil migration through the endothelial lining of the extravascular space. Colchicine also prevents the uterine oedematous response to oestrogen (Soto \& Tchernitchin, 1979). Eosinophil migration could, therefore, provide a common denominator between water imbibition and protein synthesis via the polyamine synthetic pathway. The results presented in this study do not preclude the possibility of such an event.

We thank Dr J. R. Fozard, Merrell International, for the supply of DFMO. K.M. was supported by the Pharmaceutical Society of Great Britain.

\section{References}

Bulger, W.H. \& Kupfer, D. (1976) Induction of uterine ornithine decarboxylase by antioestrogens. Inhibition of oestradiol-mediated induction of ornithine decarboxylase $A$ possible mechanism of action of antioestrogens. Endocrine Res. Commun. 3, 209-218.

Castracane, V.D. \& Jordon, V.C. (1976) Considerations into the mechanisms of oestrogen-stimulated uterine prostaglandin synthesis. Prostaglandins 12, 243-251.

Chen, K.U., Kyriakidis, D.A. \& Canellakis, E.S. (1982) The inhibition of the serum-stimulated increase of ornithine decarboxylase by ionophores and local anaesthetics. Biochim. Biophys. Acta 716, 72-78.

Danzin, C., Jung, M.J., Grove, T. \& Bey, P. (1979) Effect of $\alpha$-difluoromethylornithine, an enzyme-activated irreversible inhibitor of ornithine decarboxylase, on polyamine levels in rat tissues. Life Sci. 24, 519-524.

Das, R. \& Kanungo, M.S. (1982) Activity and modulation of ornithine decarboxylase concentrations of polyamines in various tissues of rats a function of age. Expl Gerontol. 17, 95-103.

Fozard, J.R., Part, M.L., Prakash, J., Grove, P.J., Schecter, A., Sjoerdsma, A. \& Koch-Weser, J. (1980a) L-Ornithine decarboxylase: an essential role in early embryogenesis. Science, N.Y. 208, 505-508.
Fozard, J.R., Prakash, N.J. \& Grove, J. (1980b) Ovarian function in the rat following irreversible inhibition of ornithine decarboxylase. Life Sci. 27, 2277-2283.

Lavia, L.A., Stohs, S.J. \& Lemon, H.M. (1983) Polyamine biosynthetic decarboxylase activities following oestradiol-17\% or oestriol stimulation of the immature rat uterus. Steroids 42, 609-618.

Levy, C., Mester, J. \& Baulieu, E.E. (1981) Early inhiition by progesterone of oestrogen-induced ornithine decarboxylase activity in the chick oviduct and rat uterus. J. Endocr. 90, 1-7.

Majid, E. (1981) Mechanisms involved in rat uterine responses to oestrogen. Ph.D. thesis, University of Bradford.

Manni, A. \& Wright, C. (1983) Effect of tamoxifen and $\alpha$-DFMO on doses of nitromethylurea-induced rat mammary tumour cells grown in agar culture. Cancer Res. 43, 1-84-1086.

Nakadate, T., Yamamoto, S., Ishii, M. \& Kato, R. (1982) Inhibition of 12-O-tetradecanoylphorbol-13-acetateinduced epidermal ornithine decarboxylase activity by lipoxygenase inhibitors: possible role of product(s) of lipoxygenase pathway. Carcinogenesis 12, 1411-1414. 
Phaily, S. \& Senior, J. (1978) Modification of oestrogeninduced uterine hyperaemia by drugs in ovariectomized rats. J. Reprod. Fert. 53, 91-97.

Prakash, N.J., Schecter, P.J., Grove, J. \& Koch-Weser, I. (1978) Effect of $\alpha \mathrm{DFMO}$, an enzyme activated irreversible inhibitor of ornithine decarboxylase on L1210 leukemia in mice. Cancer Res. 38, 3059-3062.

Rorke, E.A. \& Katzenellenbogen, B.S. (1984) Dissociated regulation of growth and ornithine decarboxylase activity by estrogen in the rat uterus. Biochem. Biophys. Res. Commun. 122, 1186-1193.

Russell, D.H. \& Taylor, R.L. (1971) Polyamine synthesis in the uterus of the ovariectomised rat in response to estradiol-17ß. Endocrinology 88, 1397-1403.

Slotkin, T.A., Seidler, F.J., Trepanier, P.A., Whitmore, W.L., Lerea, L., Barnes, G.A., Weigel, S.J. \& Bartholome, J. (1982) Ornithine decarboxylase and polyamines in tissues of the neonatal rat: effects of a-DFMO, a specific irreversible inhibitor of ornithine decarboxylase. J. Pharmacol. exp. Ther. 222, 741-745.

Snedecor, G.W. \& Cochran, W.G. (1979) Statistical Methods, 7 th edn. Iowa State University Press, Ames.
Soto, N. \& Tchernitchin, A. (1979) Colchicine estrogen interactions. Experientia 35, 558-559.

Tabor, C.W. \& Tabor, H. (1976) 1,4-Diaminobutane (putrescine), spermidine and spermine. Ann. Rev. Biochem. 45, 285-306.

Tchernitchin, A.N. \& Galand, P. (1982) Dissociation of separate mechanisms of estrogen action by actinomycin D. Experientia 38, 511-513.

Tsuchiya, M., Walsh, G.M. \& Frohlich, E.D. (1977) Systemic haemodynamic effects of microspheres in conscious rats. Am. J. Physiol. 233, H617-H621.

Webster, R.A., Zaloudek, C.J. \& Inman, B.C. (1984) Stimulation of uterine ornithine decarboxylase in organ culture by decreasing osmolarity: possible relation to in vivo mechanisms. Life Sci. 34, 1281-1286.

Wing, L.Y.C. \& Rillema, J.A. (1983) Prostaglandin stimulation of ornithine decarboxylase activity in mammary gland explants from mid-pregnant mice. Prostaglandins 25, 321-333.

Received 14 June 1985 